\title{
Preparation and Properties of Lauryl Alcohol-Caprylic Acid Eutectics/Activated Charcoal Composites as Shape-stabilized Phase Change Materials for Cold Energy Storage
}

\author{
Yuan LIU, Yanghua CHEN* \\ College of Mechatronics Engineering, Nanchang University, Nanchang 330031, China \\ crossref http://dx.doi.org/10.5755/j01.ms.26.3.21371
}

Received 02 August 2018; accepted 18 December 2018

\begin{abstract}
A novel form-stable composite phase change materials for cold energy storage were prepared using physical blending adsorption method. In the shape-stabilized composites, lauryl alcohol (LA) and caprylic acid (CA) were employed as phase change materials, which were blended together at specific mass ratio based on theoretical calculations. Activated charcoal (AC) was selected as supporting material due to its advantages like large specific surface area and high thermal conductivity. The composites were characterized by field emission scanning electron microscope (FE-SEM), Fourier transform infrared spectrometer (FT-IR), differential scanning calorimeter (DSC) and thermogravimetric analyzer (TGA). The results of FE-SEM and FT-IR displayed that the eutectics of LA and CA was well absorbed and dispersed homogeneously into the porous network structure of the $\mathrm{AC}$ and the melted eutectics was not easy to leak from the reticular structure. Moreover, there was only physical absorption between the eutectic mixture and AC. The results of DSC and TGA indicated that phase change temperature and latent heat of the prepared composites increased with the increase of the binary eutectics mass ratio and AC can enhance the thermal stability of composites. The composites with the mass ratio $60 \%$ of the eutectics melted at $-0.21{ }^{\circ} \mathrm{C}$ with a latent heat enthalpy of $28.08 \mathrm{~J} / \mathrm{g}$ and solidified at $-2.33{ }^{\circ} \mathrm{C}$ with a latent solidification enthalpy of $29.70 \mathrm{~J} / \mathrm{g}$. The prepared composites will contribute to cold energy storage of low temperature range.

Keywords: eutectics, shape-stabilized composites, activated carbon, cold energy storage, physical blending adsorption method.
\end{abstract}

\section{INTRODUCTION}

With the depletion of fossil flues and the rapid development of human society, the contradiction between energy supply and demand has become increasingly serious in recent decades [1]. Thermal energy storage has attracted more and more attention of researchers, which is mainly classified into three types: sensible heat storage, latent heat storage and thermochemical energy storage [2]. Comparing to sensible heat storage, latent heat storage possesses higher energy storage density and approximately isothermal process during the energy storage and release. Meanwhile, the operating temperature range of thermochemical energy storage is usually within $200{ }^{\circ} \mathrm{C}-400 \mathrm{C}$, which is not suitable for thermal storage in daily life [3]. And the technology is still in the laboratory stage and further refining of the technology through research experience is required on commercial applications. Therefore, latent heat storage based on phase change materials has been applied in different applications like greenhouse [4], heating and cooling of buildings [5], photovoltaic electricity generation [6], food conserving [7], industrial waste heat recovery [8], domestic refrigerators [9], solar power plants [10], solar drying system [11].

Phase change materials(PCMs) on the basis of phase transformation can be divided into solid-solid PCMs, solidliquid PCMs, solid-gas PCMs, liquid-gas PCMs. However, solid-solid PCMs and solid-liquid PCMs are most practical value [12]. Solid-liquid PCMs have been investigated widely and commercially produced in the latent heat storage family. It includes organic materials (paraffin, sugar alcohol, fatty acid, glycols), inorganic materials (salt hydrates, molten salts, metals) and eutectics [13]. Organic solid-liquid PCMs have the pros of chemical stability, wide operating temperature range, non-toxic, non-corrosive, less or no subcooling during solidification process, but such materials still have the cons of inflammability, low thermal conductivity, leakage and large volume variation [14]. These drawbacks restrict the direct use of organic solidliquid PCMs. Therefore, encapsulation technology of PCMs has been developed extensively by many scholars [15] They focus on developing materials as containers and creating many methods to encapsulate PCMs. According to the size of containers, there are divided into micro encapsulation and macro encapsulation. Although some of macro encapsulation containers like aluminium panels, metal spherical balls, PVC panels, plastic bags can prevent the fluid exudation during the phase transition from solid to liquid, heat transfer efficiency is reduced during the freezing process [16]. Micro encapsulation using supporting materials can enhance the heat transfer rate and protect the PCMs from the effect of ambient [17]. Among the previous literatures, many organic or inorganic supporting materials are developed to remedy undesirable shortcomings of organic solid-liquid PCMs. Organic supporting materials based on polymers such as cellulose diacetate [18], ethylene

\footnotetext{
${ }^{*}$ Corresponding author. Tel.: +86-13970944938.

E-mail address: 545422685@qq.com (Y. Chen)
} 
propylene diene terpolymer plastic [19], high density polyethylene [20] may release harmful gas like formaldehyde. In recent years, inorganic supporting materials especially carbon family have been employed due to their excellent features that are porous structure, high specific surface area, good thermal stability, non toxicity and non-corrosiveness. Many shape-stabilized composite phase change materials (CPCMs) using inorganic supporting materials such as expanded graphite [21], diatomite [22], expanded perlite [23], graphene oxide [24], expanded vermiculite [25], activated montmorillonite [26], activated carbon [27], carbon nanotubes [28] are preferred. Activated carbon has wide applications such as decolorization of sugar, military gas mask, cigarette filter, air purifier and so on, but there are a few researches on its application in the field of phase change material. Eutectics with lower melting temperature than those of original component PCMs can be obtained by blending two or more organic PCMs together in a specific mass ratio, which may extend the applications of PCMs with the desirable phase transition temperature [29]. Among the literatures obtained, relevant researches on fatty acids eutectics or sugar alcohols eutectic mixture were reported by many scholars [30-33], and some of the binary eutectics are encapsulated using supporting materials [34]. Furthermore, most of organic phase change materials reported in the literatures experience phase transition in the temperature from $5^{\circ} \mathrm{C}$ to $80{ }^{\circ} \mathrm{C}$ [35]. There are few report on the eutectic mixture of fatty acids and alcohols much less using supporting materials to encapsulate the eutectics.

In this work, preparation and properties of lauryl alcohol and caprylic acid eutectics/activated charcoal composites as shape-stabilized phase change material using physical blending adsorption method are reported. Lauryl alcohol and caprylic acid as phase change materials were blended together in the specific mass ratio that was calculated on the Schroeder formula. Then form-stable composites were prepared by adding activated carbon as supporting material into the melted eutectics. And the prepared composites were characterized using FE-SEM, FTIR, DSC and TGA. By analyzing the results of the above characterizations, the prepared form-stable composites can be utilized for applications such as domestic refrigerators and commercial refrigerated products during the phase transition on the low temperature range from $-20^{\circ} \mathrm{C}$ to $5^{\circ} \mathrm{C}$.

\section{EXPERIMENTAL}

\subsection{Materials}

Lauryl alcohol $\left(\mathrm{C}_{12} \mathrm{H}_{26} \mathrm{O}\right.$, dodecyl alcohol, AR) and caprylic acid $\left(\mathrm{C}_{8} \mathrm{H}_{16} \mathrm{O}_{2}, A R\right)$ were obtained from Aladdin Chemical Reagent CO., Ltd.. Activated charcoal $(\geq 200$ meshes, Aladdin Chemical Reagent CO., Ltd.) was selected as the supporting material.

\subsection{Preparation of the LA-CA binary eutectics/AC composites}

\subsubsection{Theoretical prediction of the LA-CA binary eutectics mass ratio}

The Schroeder formula [36] based on the phase equilibrium theory and the second law of thermodynamics.
It provides theoretical guidance for predicting the relationship between the minimum eutectics point of the binary mixture $T$ and the mole fraction $x_{i}$ of the corresponding component $i$ under the premise that the melting temperature $T_{i}$ and latent heat of fusion $\Delta H_{i}$ of the binary eutectics composition are known.

Schrader equation is presented below [37]:

$T=\left(\frac{1}{T_{i}}-\frac{R \ln x_{i}}{\Delta H_{i}}\right)^{-1},(i=A, B)$,

where $T_{i}, \Delta H_{i}$ and $x_{i}$ denote the melting temperature, the melting enthalpy and the molar fraction of the component $i$, respectively. $T$ represents the melting temperature of the mixture. $R$ is the gas constant $(8.314 \mathrm{~J} /(\mathrm{K} \cdot \mathrm{mol})) . x_{A}$ and $x_{B}$ are the mole fraction of the component $\mathrm{A}$ and $\mathrm{B}$ in the binary eutectics $\left(x_{A}+x_{B}=1\right)$

The melting enthalpy of the binary eutectics is obtained from formula as following [38]:

$$
\begin{aligned}
& H=T \sum_{i=1}^{n}\left[x_{i} H_{i} / T_{i}\right]+T \sum_{i=1}^{n}\left[x_{i}\left(C_{P L i}-C_{P S i}\right) \ln \left(T / T_{i}\right)\right], \\
& (i=A, B),
\end{aligned}
$$

where $H$ is the melting enthalpy of the eutectics, $\mathrm{J} / \mathrm{mol} ; C_{P S i}$ and $C_{P L i}$ represent the specific heat at constant pressure of the component $\mathrm{i}$ in the solid state and liquid state, respectively.

$T \sum_{i=1}^{n}\left[x_{i}\left(C_{P L i}-C_{P S i}\right) \ln \left(T / T_{i}\right)\right]$ denotes the sensible heat of mixture, which can be neglected due to its small value. So the formula is simplified as:

$$
H=T \sum_{i=1}^{n}\left(x_{i} H_{i} / T_{i}\right) \quad(i=A, B)
$$

The melting temperature and the melting enthalpy of the LA was $23.7^{\circ} \mathrm{C}$ and $217.69 \mathrm{~J} / \mathrm{g}$ and the melting temperature and the melting enthalpy of the $\mathrm{CA}$ was $15.78^{\circ} \mathrm{C}$ and $149 \mathrm{~J} / \mathrm{g}$ [39]. According to Eq. 1, the phase diagram of LA and CA binary eutectics system was shown in Fig. 1.

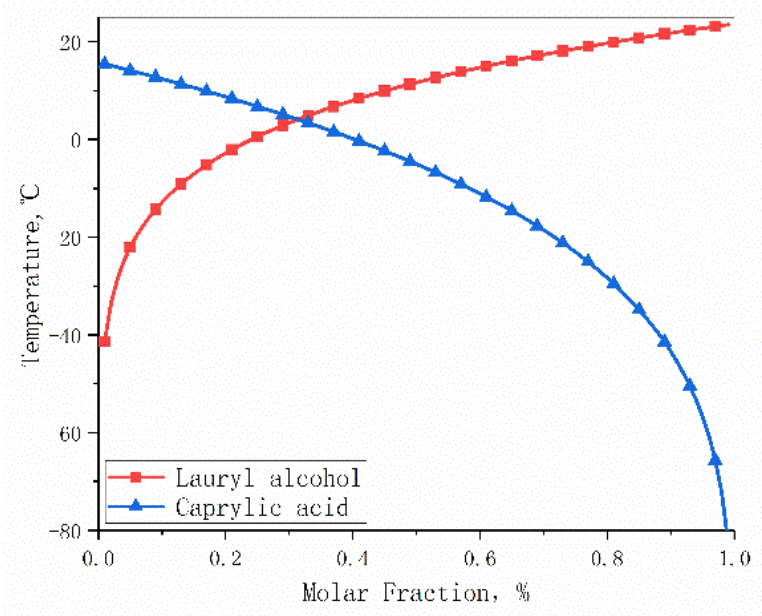

Fig. 1. The predicted phase diagram of the lauryl alcohol-caprylic acid binary eutectics 
It can be seen that the molar fraction of the component LA corresponding to the minimum eutectics point is $31 \%$. In the following work, the mixture of molar fraction $\mathrm{LA}: \mathrm{CA}=31: 69$ (namely mass ratio $\mathrm{LA}: \mathrm{CA}=36.3: 63.7$ ) was used as PCMs. Meanwhile, the melting enthalpy of the LACA mixture corresponding to the minimum eutectics point was calculated by Eq. 3. The theoretical value was $25906 \mathrm{~J} / \mathrm{mol}$, namely $42.28 \mathrm{~J} / \mathrm{g}$.

\subsubsection{Preparation of the eutectics/AC composites}

First, a certain amount of activated carbon (tabulated in Table 1) was weighed and placed in a beaker, and dried in the vacuum drying oven at $70^{\circ} \mathrm{C}$ for 24 hours to discharge the gas in the pores of the activated carbon. A mixture of LA-CA (mass ratio:36.7:63.3) was uniformly blended together in one beaker. Then the beaker was put into a thermostatic water bath at $65^{\circ} \mathrm{C}$ and stirred with a magnetic stirrer at $800 \mathrm{rpm} / \mathrm{min}$ for $1 \mathrm{~h}$ until the mixture was melted completely. Dried activated charcoal was added into the beaker while the constant temperature magnetic stirring water bath still kept original temperature and stirring speed. Finally, five kinds of the the LA-CA binary eutectics/AC composites named CPCM1, CPCM2, CPCM3, CPCM4, CPCM5 were dried in the vacuum oven for $24 \mathrm{~h}$.

Table 1. The compositions of LA-CA binary eutectics and activated carbon

\begin{tabular}{|c|c|c|}
\hline Samples & LA-CA binary eutectics, $\mathrm{g}$ & activated carbon, $\mathrm{g}$ \\
\hline CPCM1 & 10 & 15 \\
\hline CPCM2 & 10 & 12.2 \\
\hline CPCM3 & 10 & 10 \\
\hline CPCM4 & 10 & 8.2 \\
\hline CPCM5 & 10 & 6.7 \\
\hline
\end{tabular}

\subsection{Characterizations}

A field emission scanning electron microscope (FESEM, JSM6701F, JEOL, Japan) was used to observe the microstructure of the $\mathrm{AC}$ and five samples. A fourier transform infrared spectrometer (FT-IR, Nicolet5700) was selected to analyze the chemical structure of AC, LA-CA eutectics, five samples, which were recorded the infrared spectrum from $4000 \mathrm{~cm}^{-1}$ to $400 \mathrm{~cm}^{-1}$ with an accuracy of $0.09 \mathrm{~cm}^{-1}$ using $\mathrm{KBr}$ tablets. A differential scanning calorimeter (DSC, DSC8500) was utilized to measure the thermal properties of five samples at a heating or cooling rate of $5{ }^{\circ} \mathrm{C} / \mathrm{min}$ under the nitrogen purge atmosphere of $20 \mathrm{ml} / \mathrm{min}$. A thermogravimetric analyzer (TGA4000, PE) was used for investigating the thermal stability of AC, LACA eutectics, five samples from room temperature to $700{ }^{\circ} \mathrm{C}$ at a rate of $20^{\circ} \mathrm{C} / \mathrm{min}$ under the nitrogen atmosphere of $20 \mathrm{ml} / \mathrm{min}$.

\section{RESULTS AND DISCUSSION}

\subsection{Microstructure analysis}

Fig. 2 displays the microstructure images of the AC and five samples. Fig. 2 a shows the morphology of the activated charcoal. It can be seen that activated charcoal has rough surface with well-developed porous network structure and large inner specific surface area, which can be saturated with the melted eutectic mixture. This result is consistent with those of the other literatures that used activated carbon as supporting material $[27,41]$. As shown in Fig. $2 \mathrm{~b}-\mathrm{f}$, by virtue of the capillary force and surface tension between the eutectics and the activated carbon, the binary eutectics with different mass ratio $(40: 60,45: 55,50: 50,55: 45,60: 40)$ in the composites is well adsorbed into the pore structure of the activated carbon. And under the stimulation of high-energy electron beam during the SEM test, the melted eutectics in the composites still has a relatively regular shape structure. It can be explained that activated carbon can provide certain mechanical strength for composites to protect the melted eutectics from leakage. This result is consistent with those of the other literatures that used carbon family as supporting material $[34,42]$.

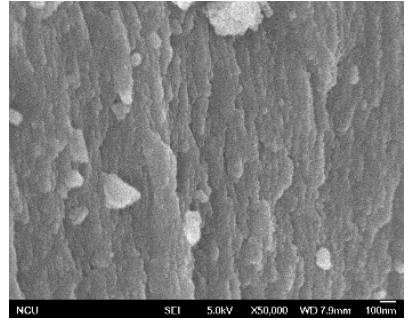

a

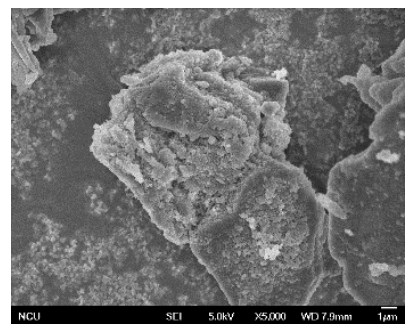

c

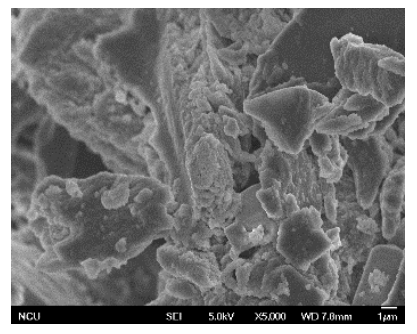

e

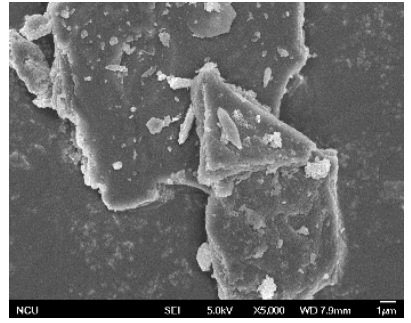

b

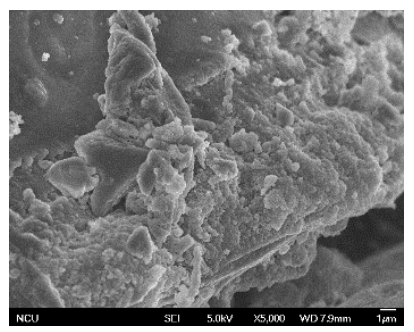

$\mathrm{d}$

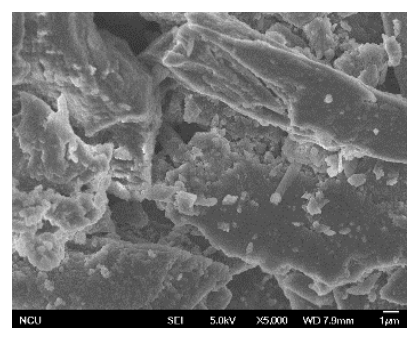

f
Fig. 2. SEM images of the activated carbon and five samples: $\mathrm{a}$-activated charcoal $(50 \mathrm{k} \times) ; \quad \mathrm{b}-$ CPCM1 $(5 \mathrm{k} \times)$; $\mathrm{c}-\mathrm{CPCM} 2(5 \mathrm{k} \times)$; d-CPCM3 (5k×); e-CPCM4 (5k×); $\mathrm{f}-\mathrm{CPCM} 5\left(5 \mathrm{k}^{\times}\right)$

\subsection{FT-IR analysis}

Fig. 3 illustrates the FT-IR spectra of the LA-CA binary eutectics, AC, five samples. The FT-IR spectrum of the LACA binary eutectics is displayed in Fig. 3 a. The peaks at $3419.34 \mathrm{~cm}^{-1}$ and $1597.28 \mathrm{~cm}^{-1}$ correspond to the stretching vibration and bending vibration of the $-\mathrm{OH}$ group in water molecules. The peaks at $2927.08 \mathrm{~cm}^{-1}$ and $2857.53 \mathrm{~cm}^{-1}$ signify the asymmetric and symmetric stretching vibration of its $-\mathrm{CH}_{2}$ group. The peak at $2671.96 \mathrm{~cm}^{-1}$ is attributed to the stretching vibration of the $-\mathrm{OH}$ group in caprylic acid. A series of characteristic peaks from $1461.64 \mathrm{~cm}^{-1}$ to $1348.01 \mathrm{~cm}^{-1}$ signify the in-plane bending vibration of the $-\mathrm{OH}$ group. The peaks at $1413.09 \mathrm{~cm}^{-1}$ and $1273 \mathrm{~cm}^{-1}$ ascribes to the in-plane bending vibration of the $-\mathrm{OH}$ 
functional group, respectively. The bands from $1231.25 \mathrm{~cm}^{-}$ ${ }^{1}$ to $1054.53 \mathrm{~cm}^{-1}$ represent the stretching vibration of the $\mathrm{C}-\mathrm{O}$ bond in the eutectics. The peaks at $935.81 \mathrm{~cm}^{-1}$ and $723.78 \mathrm{~cm}^{-1}$ are interrelated with the out-of-plane bending vibration of the $-\mathrm{OH}$ group and $\mathrm{C}-\mathrm{H}$ bond, respectively. The spectra of activated charcoal are shown in Fig. $3 \mathrm{~b}$. The peaks at $3742.23 \mathrm{~cm}^{-1}, \quad 3449.37 \mathrm{~cm}^{-1}$ and $1597.32 \mathrm{~cm}^{-1}$ results in the $-\mathrm{OH}$ group in water molecules that was absorbed in activated charcoal [40]. The asymmetric and symmetric stretching vibration of its $-\mathrm{CH}_{2}$ group correspond to the absorption peaks at $2928.95 \mathrm{~cm}^{-1}$ and $2822.69 \mathrm{~cm}^{-1}$. The peak at $1384.18 \mathrm{~cm}^{-1}$ is assigned to the in-plane bending vibration of the $\mathrm{C}-\mathrm{H}$ bond in $-\mathrm{CH}_{3}$ group. From Fig. $3 \mathrm{c}-\mathrm{g}_{2}$ the spectra of the CPCM1 to CPCM5 cover all the characteristic absorption peaks of the eutectics and activated charcoal, which indicates that there is only physical absorption, no chemical reaction and no peak shift between the eutectics and activated charcoal. The eutectics is adsorbed into the porous network of the activated charcoal. Similar results were reported by previous literatures [41].

The results of FT-IR and FE-SEM indicated that the binary eutectics was well absorbed and uniformly dispersed in the porous structure of the activated carbon owing to the surface tension and capillary force and no chemical reaction but physical absorption occurred due to the synergistic effect between LA-CA eutectics and AC.

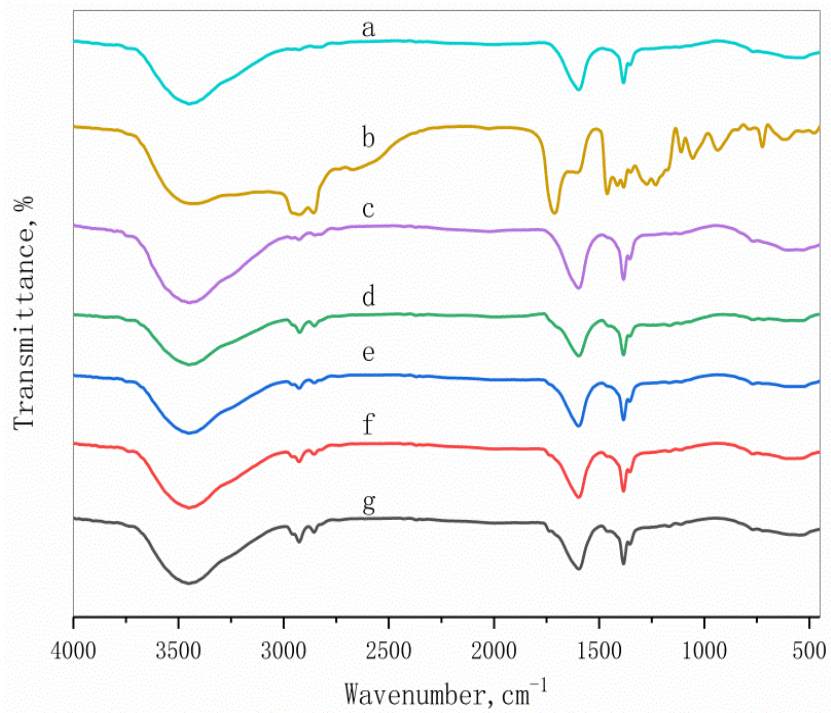

Fig. 3. FT-IR spectrum of the: a-LA-CA binary eutectics; b-activated charcoal; $c-C P C M 1 ; d-C P C M 2 ; e-C P C M 3$; f-CPCM4; g-CPCM5

\subsection{Thermal properties analysis}

Fig. 4 and Fig. 5 present the DSC graphs of the CPCM3, CPCM4, CPCM5, and the thermal performance parameters of five samples are tabulated in Table 2. As seen in Fig. 5, there are three similar exothermic peaks displayed in the solidifying DSC curves of the three samples. It is indicated that the mixture of lauryl alcohol and caprylic acid in the prepared composites was well formed into the eutectics. The experimental result is in line with the theoretical prediction. As also seen in Fig. 4, there are two endothermic peaks occuring in the melting DSC curves of the CPCM3, CPCM4 and CPCM5. This may be because part of the eutectics on the surface of activated carbon melted first than the eutectics adsorbed into the pores network structure of activated carbon during the heating process, thereby generating thermal hysteresis.

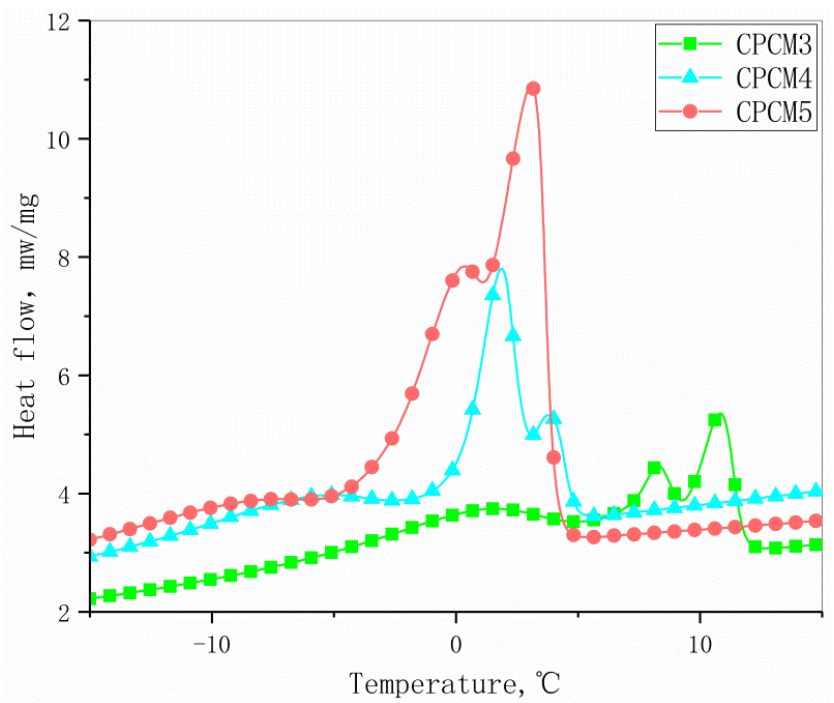

Fig. 4. The melting DSC graphs of the CPCM3, CPCM4 and CPCM5

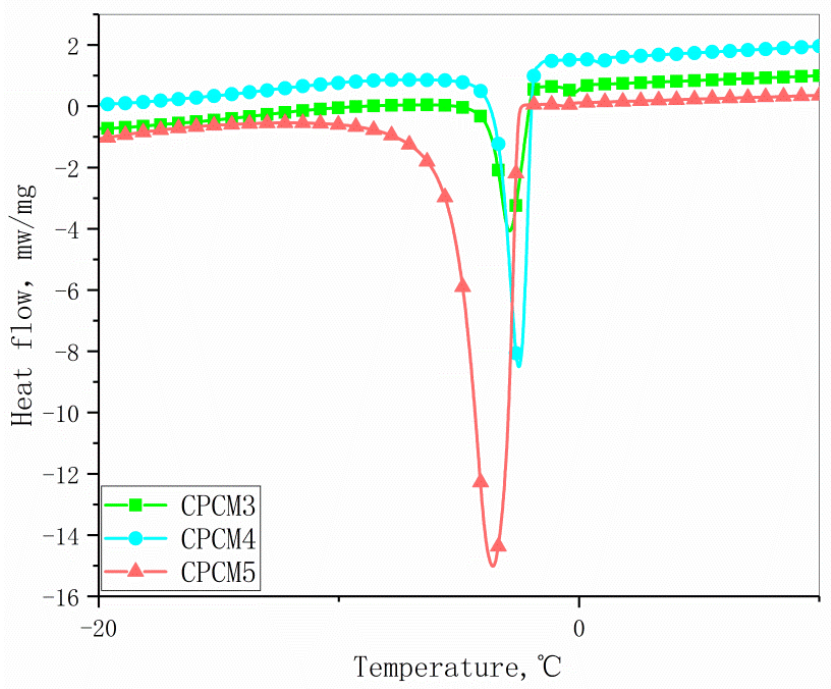

Fig. 5. The solidifying DSC graphs of the CPCM3, CPCM4 and CPCM5

As listed in Table 2, the solidification temperature of CPCM1, CPCM2, CPCM3, CPCM4, CPCM5 is $-15.92{ }^{\circ} \mathrm{C},-12.30{ }^{\circ} \mathrm{C},-1.96{ }^{\circ} \mathrm{C},-1.62{ }^{\circ} \mathrm{C},-2.33^{\circ}$ $\mathrm{C}$, respectively, and the melting temperature of CPCM1, CPCM2, CPCM3, CPCM4, CPCM5 is $-12.96{ }^{\circ} \mathrm{C},-12.32{ }^{\circ} \mathrm{C},-0.24{ }^{\circ} \mathrm{C},-5.48{ }^{\circ} \mathrm{C},-0.21^{\circ}$ $\mathrm{C}$, respectively. The melting temperatures of the composites are lower than the theoretical minimum eutectic point $\left(3{ }^{\circ} \mathrm{C}\right)$ of the pure eutectics. It can be explained that the high thermal conductivity of activated carbon makes the thermal reactivity of the composites greatly improved $[41,42]$. The supercooling of the CPCM1, CPCM2, CPCM3, CPCM4, CPCM5 are $2.96{ }^{\circ} \mathrm{C}, 0.02{ }^{\circ} \mathrm{C}, 1.72{ }^{\circ} \mathrm{C}, 3.86{ }^{\circ} \mathrm{C}, 2.12^{\circ} \mathrm{C}$, respectively, which are within an acceptable range. It is also shown in Table 2 that with the decrease of activated carbon in the composites, the latent heat of melting and solidification of composites increases. 
Table 2. DSC data of the CPCM1-CPCM5

\begin{tabular}{|c|c|c|c|c|c|c|c|}
\hline \multirow{2}{*}{ Samples } & \multicolumn{2}{|c|}{ Melting points } & \multirow{2}{*}{$\begin{array}{l}\text { Melting enthalpy, } \\
\mathrm{J} / \mathrm{g}\end{array}$} & \multicolumn{2}{|c|}{ Solidifying points } & \multirow{2}{*}{$\begin{array}{l}\text { Solidifying } \\
\text { enthalpy, J/g }\end{array}$} & \multirow{2}{*}{$\begin{array}{c}\text { Supercooling } \\
\text { degree, },{ }^{\circ} \mathrm{C}\end{array}$} \\
\hline & Tonset, ${ }^{\circ} \mathrm{C}$ & Tpeak, ${ }^{\circ} \mathrm{C}$ & & Tonset, ${ }^{\circ} \mathrm{C}$ & Tpeak, ${ }^{\circ} \mathrm{C}$ & & \\
\hline CPCM1 & -12.96 & -9.38 & 1.34 & -15.92 & -20.61 & 3.70 & 2.96 \\
\hline СРCM2 & -12.32 & -7.12 & 4.05 & -12.30 & -19.40 & 7.25 & 0.02 \\
\hline CPCM3 & $-0.24,2.09$ & $0.78,3.41$ & 3.67 & -1.96 & -2.85 & 6.11 & 1.72 \\
\hline CРCM4 & -5.48 & 1.75 & 13.55 & -1.62 & -2.18 & 14.20 & 3.86 \\
\hline CPCM5 & -0.21 & 3 & 28.08 & -2.33 & -3.34 & 29.70 & 2.12 \\
\hline
\end{tabular}

However, the melting enthalpy of the five samples are lower than theoretical melting enthalpy of the pure eutectics. This is because only the eutectics in per unit mass composites absorbs and releases heat during phase transition. Based on the above analysis, CPCM5 is considered as the desirable sample in this experiment.

Table 3 summarizes comparison of the thermal performance parameters of the composites between this experiment and other literatures. Comparing to the latent heat of salt hydrate, the melting enthalpy of prepared composites is much lower, but there are less or no supercooling and no phase separation of the prepared materials for cold energy storage. Moreover, activated carbon can act as nucleating agent during the solidification of the eutectics, which is conducive to lower supercooling and enhance the heat exchange rate.

\subsection{Thermal stability analysis}

Fig. 6 exhibits the TGA graphs of the LA-CA binary eutectics, AC, CPCM1, CPCM2, CPCM3, CPCM4, CPCM5. The onset temperature of the mass loss ( $\left.T_{\text {onset }}\right)$, the temperature of maximum mass loss rate $\left(T_{\text {peak }}\right)$ and the charred residue amount of the LA-CA binary eutectics, AC and the five samples are presented in Table 4. As seen in Fig. 6, the LA-CA binary eutectics has only one thermal decomposition process. The thermal degradation trend of the five samples is almost the same, which indicates that the thermal degradation rate of the prepared composites is slower compared with that of the eutectics. Meanwhile, there are two thermal decomposition process of activated carbon. The weight loss from $80^{\circ} \mathrm{C}$ to $125^{\circ} \mathrm{C}$ corresponds to the evaporation of water molecular absorbed into AC. The second thermal degradation is related to activated charcoal from the beginning of $270^{\circ} \mathrm{C}$. As listed in Table 4, the LACA binary eutectics at $277^{\circ} \mathrm{C}$ is complete combustion while the residue amount of the activated carbon and the CPCM1, CPCM2, CPCM3, CPCM4, CPCM5 are $83.73 \%$, $76.51 \%$, $73.23 \%, 68.45 \%, 61.63 \%, 57.66 \%$, respectively. This result by TGA is in good agreement with the results by DSC analysis. The residue amount of the five samples is smaller when the mass ratio of activated carbon in the composites is larger. And it is also indicated that activated charcoal as supporting material can enhance the thermal stability of the composites by building up physical protective barrier based on carbonaceous layers. Similar results can be obtained from previous literatures [21, 22].

On the basis of the analysis of DSC and TGA, it is known that CPCM5 has a suitable phase transition temperature, good thermal stability and the phase enthalpy is larger than that of other four samples. CPCM5 melted at $-0.21{ }^{\circ} \mathrm{C}$ with a latent heat enthalpy of $28.08 \mathrm{~J} / \mathrm{g}$ and solidified at $-2.33{ }^{\circ} \mathrm{C}$ with a latent solidification enthalpy of $29.70 \mathrm{~J} / \mathrm{g}$ as the mass ratio of the eutectics is $60 \%$. Therefore, it was selected as the most desirable sample for this experiment. In the previous literatures, the thermal conductivity of composites using carbon family like activated carbon as supporting material can be enhanced comparing to that of the organic PCMs. The thermal conductivity of activated charcoal was measured as $0.165 \mathrm{~W} /(\mathrm{m} \cdot \mathrm{K})$ in melting state $\left(50{ }^{\circ} \mathrm{C}\right)$ and $0.144 \mathrm{~W} /(\mathrm{m} \cdot \mathrm{K})$ in solidifying state $\left(25^{\circ} \mathrm{C}\right)$ [41]. Meanwhile, Tumirah Khadiran et.al [42] measured that the thermal conductivity of activated charcoal was $0.262 \mathrm{~W} /(\mathrm{m} \cdot \mathrm{K})$ in freezing state $\left(25^{\circ} \mathrm{C}\right)$ and $0.289 \mathrm{~W} /(\mathrm{m} \cdot \mathrm{K})$ in melting state $\left(35^{\circ} \mathrm{C}\right)$. Although there is different test results on the same thermal parameter of AC, these data still provide some evidence that $\mathrm{AC}$ can enhance the thermal conductivity of the prepared composites to some extent.

Table 3. Comparison of thermo-physical properties between the present work and other literatures

\begin{tabular}{|l|c|c|c|c|c|c|c|}
\hline \multicolumn{1}{|c|}{ Materials } & Type & $\begin{array}{c}\text { Melting } \\
\text { point, }{ }^{\circ} \mathrm{C}\end{array}$ & $\begin{array}{c}\text { Melting } \\
\text { enthalpy, } \mathrm{J} / \mathrm{g}\end{array}$ & $\begin{array}{c}\text { Solidifying } \\
\text { point, }{ }^{\circ} \mathrm{C}\end{array}$ & $\begin{array}{c}\text { Solidifying } \\
\text { enthalpy, J/g }\end{array}$ & Applications & References \\
\hline $\begin{array}{l}\text { Zein:dodecane } \\
(70: 30)\end{array}$ & Organic & -10 & 34.5 & - & - & Packaging & {$[43]$} \\
\hline $19.5 \% \mathrm{NH}_{4} \mathrm{Cl} / \mathrm{H}_{2} \mathrm{O}$ & Salt hydrate & -15.4 & - & - & - & Freezer & {$[44]$} \\
\hline $\begin{array}{l}\text { Lauric acid } / \text { activated } \\
\text { carbon }(1: 3)\end{array}$ & Composite & 43.87 & 32.45 & 41.67 & 30.08 & $\begin{array}{c}\text { Thermal } \\
\text { energy storage }\end{array}$ & {$[41]$} \\
\hline $90 \% \mathrm{NaCl} / \mathrm{H}_{2} \mathrm{O}$ & Salt hydrate & -5 & 289 & - & - & Freezer & {$[45]$} \\
\hline $\mathrm{NaNO}_{3} / \mathrm{H}_{2} \mathrm{O}$ & Salt hydrate & -18 & 306 & - & - & Freezer & {$[46]$} \\
\hline $\mathrm{LA}-\mathrm{CA} / \mathrm{AC}(3: 2)$ & Composite & -0.21 & 28.08 & -2.33 & 29.70 & Cooling & $\begin{array}{c}\text { Present } \\
\text { work }\end{array}$ \\
\hline
\end{tabular}




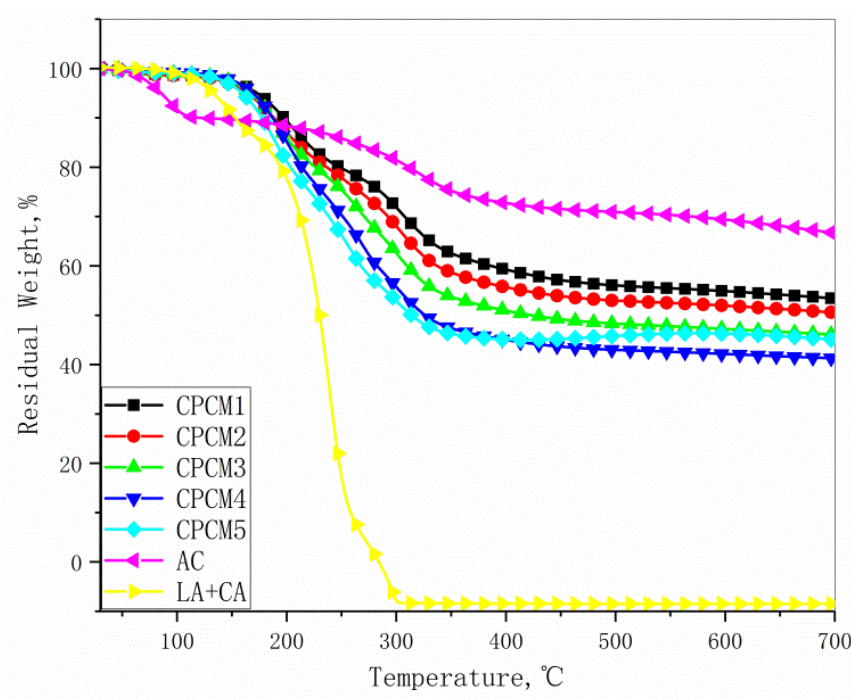

Fig. 6. TGA graphs of the LA-CA binary eutectics, activated charcoal, CPCM1, CPCM2, CPCM3, CPCM4 and CPCM5

Table 4. TGA data of the CPCM1-CPCM5

\begin{tabular}{|c|c|c|c|}
\hline Samples & $T_{\text {onset, }}{ }^{\circ} \mathrm{C}$ & $T_{\text {peak }},{ }^{\circ} \mathrm{C}$ & $\begin{array}{c}\text { Percentage of the } \\
\text { residual weight, } \% \\
\left(700^{\circ} \mathrm{C}\right)\end{array}$ \\
\hline $\begin{array}{c}\text { LA-CA } \\
\text { eutectics }\end{array}$ & 130.67 & 200 & $0\left(277^{\circ} \mathrm{C}\right)$ \\
\hline $\begin{array}{c}\text { Activated } \\
\text { carbon }\end{array}$ & 80 & 354 & 66.70 \\
\hline CPCM1 & 172 & 371 & 53.40 \\
\hline CPCM2 & 163.67 & 352 & 50.55 \\
\hline CPCM3 & 167 & 350 & 46.10 \\
\hline CPCM4 & 169 & 345 & 41.28 \\
\hline CPCM5 & 159.33 & 343 & 45.07 \\
\hline
\end{tabular}

\section{CONCLUSIONS}

A novel shape-stabilized composites for cold energy storage was prepared using the eutectics of lauryl alcohol and caprylic acid as phase change material and activated carbon as supporting material. The prepared composites were characterized by a series of methods. Based on the results obtained and relevant characterization analysis, the prepared form-stable composites have great potential for the applications of domestic refrigerators and refrigerated products. Studies have shown that PCMs incorporated into freezers created energy saving up to $12 \%$ and coefficient of performance improvement up to $19 \%$. In the following work, we will focus more attention on developing shapestabilized composites in the low temperature range.

\section{Acknowledgments}

This work is supported by the Science and Technology Support Project of Jiangxi province (Grant No.20112BBE50031).

\section{REFERENCES}

1. Du, K., Calautit, J., Wang, Z.H., Wu, Y.P., Liu, H. A Review of the Applications of Phase Change Materials in Cooling, Heating and Power Generation in Different Temperature Ranges Applied Energy 220 2018: pp. $242-273$. https://doi.org/10.1016/j.apenergy.2018.03.005

2. Baylin, F. Low Temperature Thermal Energy Storage: A State-of-the-Art Survey Energy 2(1) 1979: pp. $70-75$. https://doi.org/10.1016/0360-5442(77)90023-8

3. Elabdein, R.Z. Critical Review of Latent Heat Storage Systems for Free Cooling in Buildings Renewable \& Sustainable Energy Reviews $82(3)$ 2018: pp. $2843-2868$.

https://doi.org/10.1016/j.rser.2017.10.046

4. Vadiee, A., Martin, V. Thermal Energy Storage Strategies for Effective Closed Greenhouse Design Applied Energy 109 (2) 2013: pp. 337-343.

https://doi.org/10.1016/j.apenergy.2012.12.065

5. Zhou, Z.H., Zhang, Z.M., Zuo, J., Huang, K., Zhang, L.Y. Phase Change Materials for Solar Thermal Energy Storage in Residential Buildings in Cold Climate Renewable \& Sustainable Energy Reviews 48 2015: pp. 692-703. https://doi.org/10.1016/j.rser.2015.04.048

6. Ma, T., Yang, H.X., Zhang, Y.P., Lu, L., Wang, X. Using Phase Change Materials in Photovoltaic Systems for Thermal Regulation and Electrical Efficiency Improvement: A Review and Outlook Renewable \& Sustainable Energy Reviews 43 2015: pp. $1273-1284$.

https://doi.org/10.1016/j.rser.2014.12.003

7. Cheng, W.L., Mei, B.J., Liu, Y.N., Huang, Y.H., Yuan, X.D. A Novel Household Refrigerator with Shapestabilized PCM (Phase Change Material) Heat Storage Condensers: An Experimental Investigation Energy 36 (10) 2011: pp. 5797-5804.

https://doi.org/10.1016/j.energy.2011.08.050

8. Fang, G.Y., Tang, F., Cao, L. Preparation, Thermal Properties and Applications of Shape-stabilized Thermal Energy Storage Materials Renewable \& Sustainable Energy Reviews 40 (C) 2014: pp. 237-259. https://doi.org/10.1016/j.rser.2014.07.179

9. Belman-Flores, J.M., Barroso-Maldonado, J.M., Rodríguez-Muñoz, A.P., Camacho-Vázquez, G. Enhancements in Domestic Refrigeration, Approaching A Sustainable Refrigerator - A Review Renewable \&

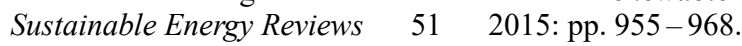
https://doi.org/10.1016/j.rser.2015.07.003

10. Aydin, D., Casey, S.P., Riffat, S. The Latest Advancements on Thermochemical Heat Storage Systems Renewable \& Sustainable Energy Reviews 41 (41) 2015: pp. 356-367. https://doi.org/10.1016/j.rser.2014.08.054

11. Shalaby, S.M., Bek, M.A., El-Sebaii, A.A. Solar Dryers with PCM as Energy Storage Medium: A Review Renewable \& Sustainable Energy Reviews 33 (2) 2014: pp. $110-116$ https://doi.org/10.1016/j.rser.2014.01.073

12. Wang, X.W., Lu, E., Lin, W.X., Liu, T., Shi, Z.S., Tang, R.S., Wang, C.Z. Heat Storage Performance of the Binary Systems Neopentyl Glycol/Pentaerythritol and Neopentyl Glycol/Trihydroxy Methyl-aminomethane as Solid-Solid Phase Change Materials Energy Conversion \& Management 41 (2) 2000: pp. 129-134. https://doi.org/10.1016/S0196-8904(99)00097-7

13. Abhat, A. Low Temperature Latent Heat Thermal Energy Storage: Heat Storage Materials Solar Energy $30(4)$ 1983: pp. $313-332$. https://doi.org/10.1016/0038-092X(83)90186-X

14. Kuznik, F., David, D., Johannes, K., Roux, J. A Review on Phase Change Materials Integrated in Building Walls 
Renewable \& Sustainable Energy Reviews

$15(1)$

2011: pp. 379-391.

https://doi.org/10.1016/j.rser.2010.08.019

15. Cabeza, L.F., Castell, A., Barreneche, C., Graciaa, A.D., Fernándezb, A.I. Materials used as PCM in Thermal Energy Storage in Buildings: A Review Renewable \& Sustainable Energy Reviews 15 (3) 2011: pp. 1675-1695. https://doi.org/10.1016/j.rser.2010.11.018

16. Jamekhorshid, A., Sadrameli, S.M., Farid, M. A Review of Microencapsulation Methods of Phase Change Materials (PCMs) as A Thermal Energy Storage (TES) Medium Renewable \& Sustainable Energy Reviews 31 (2)

2014: pp. $531-542$.

https://doi.org/10.1016/j.rser.2010.11.018

17. Liu, L.K., Alva, G., Huang, X., Fang, G.Y. Preparation, Heat Transfer and Flow Properties of Microencapsulated Phase Change Materials for Thermal Energy Storage Renewable \& Sustainable Energy Reviews 66 2016: pp. 399-414.

https://doi.org/10.1016/j.rser.2016.08.035

18. Ding, E.Y., Jiang, Y., Li, G.K. Comparative Studies of the Structures and Transition Characteristics of Cellulose Diacetate Modified with Polyethylene Glycol prepared by Chemical Bonding and Physical Blending Methods Journal of Macromolecular Science B 40 2001: pp. $1053-1068$.

https://doi.org/10.1081/MB-100107801

19. Song, G.L., Ma, S.D., Tang, G.Y., Yin, Z.S., Wang, X.W. Preparation and Characterization of Flame Retardant Formstable Phase Change Materials composed by EPDM, Paraffin and Nano Magnesium Hydroxide Energy 35 (5) 2010: pp. $2179-2183$.

https://doi.org/10.1016/j.energy.2010.02.002

20. Zhang, Y.P., Lin, K.P., Yang, R., Di, H.F., Jiang, Y. Preparation, Thermal Performance and Application of Shapestabilized PCM in Energy Efficient Buildings Energy \& Buildings $38(10) \quad$ 2006: pp. 1262-1269. https://doi.org/10.1016/j.enbuild.2006.02.009

21. Sari, A., Karaipekli, A. Preparation, Thermal Properties and Thermal Reliability of Palmitic Acid/Expanded Graphite Composite as Form-stable PCM for Thermal Energy Storage Solar Energy Materials \& Solar Cells 93 (5) 2009: pp. 571-576. https://doi.org/10.1016/j.solmat.2008.11.057

22. Li, M., Kao, H.T., Wu, Z.S., Tan, J.M. Study on Preparation and Thermal Property of Binary Fatty Acid and the Binary Fatty Acids/Diatomite Composite Phase Change Materials Applied Energy 88 (5) 2011: pp. 1606-1612. https://doi.org/10.1016/j.apenergy.2010.11.001

23. Cai, Y.B., Gao, C.T., Zhang, T., Zhang, Z., Wei, Q.F., Du, J.M., Hu, Y., Song, L. Influences of Expanded Graphite on Structural Morphology and Thermal Performance of Composite Phase Change Materials consisting of Fatty Acid Eutectics and Electrospun PA6 Nanofibrous Mats Renewable Energy 57 (3) 2013: pp. 163-170. https://doi.org/10.1016/j.renene.2013.01.044

24. Mehrali, M., Latibari, S.T., Mehrali, M., Metselaar, H.S.C., Mahyar, S. Shape-stabilized Phase Change Materials with High Thermal Conductivity based on Paraffin/Graphene Oxide Composite Energy Conversion \& Management 67 (3) 2013: pp. 275-282. https://doi.org/10.1016/j.enconman.2012.11.023

25. Sari, A., Karaipekli, A., Alkan, C. Preparation, Characterization and Thermal Properties of Lauric Acid/Expanded Perlite as Novel Form-stable Composite
Phase Change Material Chemical Engineering Journal 155 (3) 2009: pp. 899-904.

https://doi.org/10.1016/j.cej.2009.09.005

26. Wang, Y., Zheng, H., Feng, H.X., Zhang, D.Y. Effect of Preparation Methods on the Structure and Thermal Properties of Stearic Acid/Activated Montmorillonite Phase Change Materials Energy \& Buildings 47 (47)

2012: pp. $467-473$.

https://doi.org/10.1016/j.enbuild.2011.12.021

27. Feng, L.L., Zheng, J., Yang, H.Z., Guo, Y.L., Li, W., Li, X.G. Preparation and Characterization of Polyethylene Glycol/Active Carbon Composites as Shape-stabilized Phase Change Materials Solar Energy Materials \& Solar Cells 95 (2) 2011: pp. 644-650.

https://doi.org/10.1016/j.solmat.2010.09.033

28. Meng, X., Zhang, H., Sun, L.X., Xu, F., Jiao, Q.Z., Zhao, Z.M., Zhang, J., Zhou, H.Y., Sawada, Y.T., Liu, Y.L. Preparation and Thermal Properties of Fatty Acids/CNTs Composite as Shape-stabilized Phase Change Materials Journal of Thermal Analysis \& Calorimetry 111 (1) 2013: pp. $377-384$. https://doi.org/10.1007/s10973-012-2349-8

29. Sharma, S.D., Sagara, K. Latent Heat Storage Materials and Systems: A Review International Journal of Green Energy 2 (1) 2005: pp. 1-56. https://doi.org/10.1081/GE-200051299

30. Cabeza, L.F., Castell, A., Barreneche, C., Graciaa, A.D., Fernándezb, A.I. Materials used as PCM in Thermal Energy Storage in Buildings: A Review Renewable \& Sustainable Energy Reviews 15 (3) 2011: pp. 1675-1695. https://doi.org/10.1016/j.rser.2010.11.018

31. Sharma, A., Tyagi, V.V., Chen, C.R., Buddhib, D. Review on Thermal Energy Storage with Phase Change Materials and Applications Renewable \& Sustainable Energy Reviews 13 (2) 2009: pp. 318-345. https://doi.org/10.1016/j.rser.2007.10.005

32. Diarce, G., Gandarias, I., Campos-Celador, Á., GarcíaRomeroa, A., Griesser, U.J. Eutectic Mixtures of Sugar Alcohols for Thermal Energy Storage in the $50-90{ }^{\circ} \mathrm{C}$ Temperature Range Solar Energy Materials \& Solar Cells 134 (3) 2015: pp. 215-226. https://doi.org/10.1016/j.solmat.2014.11.050

33. Ma, H.K., Lin, C.P., Wu, H.P., Peng, C.H., Hsu, C.C. Waste Heat Recovery using A Thermoelectric Power Generation System in A Biomass Gasifier Applied Thermal Engineering $88(5) \quad$ 2015: pp. 274-279. https://doi.org/10.1016/j.applthermaleng.2014.09.070

34. Zeng, J.L., Chen, Y.H, Shu, L., Yu, L.P., Zhu, L., Song, L.B., Cao, Z., Sun, L.X. Preparation and Thermal Properties of Exfoliated Graphite/Erythritol/Mannitol Eutectic Composite as Form-stable Phase Change Material for Thermal Energy Storage Solar Energy Materials \& Solar Cells 178 2018: pp. 84-90. https://doi.org/10.1016/j.solmat.2018.01.012

35. Alva, G., Lin, Y.X., Fang, G.Y. An Overview of Thermal Energy Storage Systems Energy 144 2018: pp. $341-378$. https://doi.org/10.1016/j.energy.2017.12.037

36. Ke, H., Li, Y.G. Eutectic Mass Ratios, Thermal Energy Storage Properties and Applications of Multiple Fatty Acid Eutectics Journal of Materials Science and Engineering 01 2018: pp. $82-86$. http://www.en.cnki.com.cn/Article_en/CJFDTotal-CLKX201801017.htm

37. Lv, S.L., Zhu, N., Feng, G.H. Eutectic Mixtures of Capric Acid and Lauric Acid applied in Building Wallboards for Heat 
Energy Storage Energy \& Buildings 38 (6)

2006: pp. $708-711$.

https://doi.org/10.1016/j.enbuild.2005.10.006

38. Zhang, Y.P., Su, Y.H., Ge, X.S. Prediction of the Melting Temperature and the Fusion Heat of (quasi-) Eutectic PCM Journal of University of Science \& Technology China 25 1995: pp. 474-478.

http://en.cnki.com.cn/Article_en/CJFDTotal-ZKJD504.016.htm

39. Wang, S.T. Study on Organic Phase Change Materials in Energy Storage Air Conditioning System Journal of Dalian Maritime University 2008: pp. 44-46. http://kns.cnki.net/KCMS/detail/detail.aspx? dbcode=CMFD $\&$ dbname $=$ CMFD2009\& filename $=2008210067 . n h \& v=$ MD Q5MDRSTEtlWnVSbUZpRGxXcnpLVjEyN0ZyRzVIdEhL cUpFYlBJUjhlWDFMdXhZUzdEaDFUM3FUcldNMUZyQ $1 \mathrm{U}=$

40. Chen, Z., Shan, F., Cao, L., Fang, G.Y. Preparation and Thermal Properties of N-octadecane/Molecular Sieve Composites as Form-stable Thermal Energy Storage Materials for Buildings Energy \& Buildings 49 2012: pp. $423-428$.

https://doi.org/10.1016/j.enbuild.2012.02.035

41. Chen, Z., Shan, F., Cao, L., Fang, G.Y. Synthesis and Thermal Properties of Shape-stabilized Lauric Acid/Activated Carbon Composites as Phase Change Materials for Thermal Energy Storage Solar Energy Materials \& Solar Cells 102 2012: pp. 131-136. https://doi.org/10.1016/j.solmat.2012.03.013

42. Khadiran, T., Hussein, M.Z., Zainal, Z. Activated Carbon derived from Peat Soil as A Framework for the Preparation of Shape-stabilized Phase Change Material Energy 8 2015: pp. $468-478$. https://doi.org/10.1016/j.energy.2015.01.057

43. Pérez-Masiá, R., López-Rubio, A., Lagarón, J.M. Development of Zein-based Heat-management Structures for Smart Food Packaging Food Hydrocolloids $30(1)$ 2013: pp. $182-191$. https://doi.org/10.1016/j.foodhyd.2012.05.010

44. Gin, B., Farid, M.M., Bansal, P.K. Effect of Door Opening and Defrost Cycle on A Freezer with Phase Change Panels Energy Conversion \& Management 51 (12) 2010: pp. $2698-2706$. https://doi.org/10.1016/j.enconman.2010.06.005

45. Kha, M.I.H., Afroz, H.M.M. Effect of Phase Change Material on Performance of a Household Refrigerator Asian Journal of Applied Sciences 6 (2) 2004: pp. 56-67. https://doi.org/10.1080/23744731.2015.1023161

46. Oró, E., Miró, L., Farid, M.M., Cabeza, L.F. Improving Thermal Performance of Freezers using Phase Change Materials International Journal of Refrigeration 35 (4) 2012: pp. $984-991$. https://doi.org/10.1016/j.ijrefrig.2012.01.004

47. Cheng, W.L., Mei, B.J., Liu, Y.N., Huang, Y.H., Yuan, X.D. A Novel Household Refrigerator with Shapestabilized PCM (Phase Change Material) Heat Storage Condensers: An Experimental Investigation Energy 36 (10) 2011: pp. 5797-5804. https://doi.org/10.1016/j.energy.2011.08.050

48. Cheng, W.L., Yuan, X.D. Numerical Analysis of A Novel Household Refrigerator with Shape-stabilized PCM (Phase Change Material) Heat Storage Condensers Energy 59 2013: pp. $265-276$. https://doi.org/10.1016/j.energy.2013.06.045 